\title{
The influence of colonial languages on language policies of francophone sub-Saharan Africa
}

\author{
Stephanie Sophie Maba Kengne \\ mabasophie@gmail.com \\ Shanghai International Studies University, Shanghai, 200083, China
}

\begin{abstract}
Language as part of the colonial heritage has and will still stand as a challenge to the development of African languages and even bigger challenge facing language policies makers in African countries. As part of the former French colonial empire, Africa is now the most French speaking continent on the planet. In Sub-Saharan Africa in particular, although rich with numerous ethnic groups and thus languages, lots of its countries at the independence chose French as one of or the only official language of the country. This research endeavor sets out to analyze the language question in Africa, most particularly sub-Saharan African French speaking countries history and language situation, in a bid to understand the impact of French as official language on these countries' language policy and planning, analyze efforts made by some of these countries in terms of policy and planning of national languages, and possibly offer some perspectives on language planning and policy in sub-Saharan African French speaking nations.
\end{abstract}

Keywords: Sub-Saharan Africa; Language policy and planning; Language situation; French;

\section{Introduction}

Sub-Saharan Africa is the region of the African continent south of the Sahara Desert; It consists of 48 countries with a population of about 1 billion inhabitants. Linguistically and culturally diverse, the region is home to more than 1,000 languages, i.e. about one sixth of the world's total. The languages of sub-Saharan Africa are grouped into four groups: Afro-Asiatic languages, Nilo-Saharan languages, Khoisan languages and Austronesian languages. In addition, the region has other originally foreign languages, but which due to historical reasons have become part of the daily life interactions, such as French. This paper analyses the influence of French on the language policy of a set of countries located in sub-Saharan Africa, but who happen to have French as their official language or at least one of their official languages. The work is divided into three main sections: historical background, characteristics of language policies in Francophone subSaharan Africa, typical cases analysis. Some sections are broken down into subsections, and they are all considered in turn. 


\section{Historical background}

Historical records show that, French conquerors entered Africa as early as 1659, through an island in Senegal. The French named the island Saint-Louis in honor of Saint Louis, king of France. Located at the mouth of the Senegal river along the Atlantic Coast, it became their main road for slave trade. By the 18th century the island of Saint-Louis was already a well established city of about 7,000 inhabitants (Gadet, 2011:144; Nojea, 2017:146). Later on, the first French-language school was also opened on the island in 1817. Later on, Blaise Diagne, a Senegalese was elected delegate on $10^{\text {th }}$ May 1914 as the first "African" at the French Congress. Later, the expansion of The French language in Africa coincided with the expansion of the French colonial empire.

Today, Africa is home to the largest number of French speakers in the world, and the Republic of Congo has the largest number of French speakers as a country overall, followed by France. According to a 2018 report by the organization of French speaking countries La Francophonie, 59\% of people who use French in their daily lives live on the African continent. And by $2050,70 \%$ of the world's French speakers will be in Africa. At present, there are 26 countries and regions in Africa that speak French, some only use it in their daily life, while others have gone as far as upgrading French as an official language of the country. In terms of regional distribution, French is spoken in two parts of Africa: one is Northern Africa or Maghreb, where there are four French-speaking countries: Morocco, Tunisia, Algeria and Mauritania. The second is the dominant region, sub-Saharan Africa.

The introduction of French in sub-Saharan Africa can be mirrored along the history of France's colonial empire. At that time, France divided the empire into two parts: (Afrique Equatoriale Française AEF) French Equatorial Africa, including Gabon, Moyen Congo, Oubangui Chari, Central African Republic and Chad. Later, within the framework of a United Nations and the League of Nations mandate, Cameroon was added to the empire. Two is the French West Africa (Afrique Occidentale Française AOF) including: Senegal, Mauritania, (Soudan Français) present days Mali, (Haute Volta) present days Burkina Faso, (Guinee Française) Guinea (Conakry), Niger, Cote d 'Ivoire, (Dahomey) present days Benin. Added to this are the former Belgian colonies namely the Republic of Congo, Burundi and Rwanda. By the early 1950s, colonies throughout Africa have begun to negotiate their right to self-determination under the auspices of the United Nations. After much negotiation, African countries in general began to obtain their independence as early as in 1957, starting from Ghana. Among French-speaking African countries, Guinea (Conakry) was the first to become independent in 1958 following a refusal by their leader to remain within the French alliance. Most of the other countries gained independence between January and August 1960. Belgian colonies Burundi and Rwanda gained independence in July 1962, and the Republic of Congo had joined French Africa and obtained its independence in June 1960.

Today, 17 countries in sub-Saharan Africa have French as one of or their only official language. These countries include: Benin, Burkina Faso, Burundi, Cameroon, Congo, Democratic Republic of the Congo, Cote d 'Ivoire, Gabon, Guinea (Conakry), Mali, Niger, Central African Republic, Rwanda, Senegal, Chad, Togo. What these countries have in common is that, when they became independent, they adopted French as their official language while simply ignoring their own national languages. West Africa is said to have the most languages in Africa, in fact, the more ethnic groups there are, the more languages there are. So, in many cases French came up as a common language, because there were so many native languages that only a foreign language could be used in such a linguistically diverse context to ensure communication among the people. In 
Cameroon, for example, the language and culture of the country has been highly influence by English and French. Indeed, the country was partitioned between Britain and France from 1919 to 1939 and from 1946 to 1959 under a League of Nations trusteeship and a UN mandate. As a result, English and French have been chosen as Official languages since independence in 1960, although research reveal that there are about 270 local languages spoken in the country.

In France's old colonies, French was the official language, the language of instruction, the language of the media, and the working language of the government. Today, although some countries have selected one or more local language and gave it a status of official language, the actual situation, especially in the government's public service reveals that, official government communication is mainly handled in French. French is also the main language of instruction at the primary level. Some countries (Senegal and Burkina Faso, for example) encourage the use of the local language for language and mathematics instruction at the primary level to help the young learner have a better grasp, but the ultimate goal is to enable students to master and be educated in French. In the media, at the micro level there are programs in local languages but at the macro level especially programs about government, the language of broadcasting is French. These are only some few peculiarities of these countries, as they are discussed in a more detailed way in the next section.

\section{Characteristics of language policies in francophone sub-Saharan Africa}

French-speaking countries in sub-Saharan Africa are among the largest speakers of French, which was originally a foreign language but has now become an important part of those countries' history and culture. The purpose of this section is to discuss the characteristics of language policies in these countries, especially in relation to French.

First of all, French was introduced in these countries by colonial rule and has been maintained until now. At that time, the teaching and education in French was mainly to train office staff to help with state affairs and the colonial rule. Gradually, this has come to form the country's educational system, and the influence of such a system is still evident today. So, most of the contents and methods of education in these countries are modelled after the French education system. Although the status of French in these countries is complicated, it is clear that French often holds the status of official language, language of instruction and language of international communication.

Secondly, a legacy from the colonial period is that, French is the only or one of the official languages in all these countries. In fact, since French was introduced into these countries during the colonial period, it has more or less become a compulsory language in the education system, government departments and other public areas. The system has been maintained the since independence and upgrading French to the status of official language of the newly independent country only helped perpetuate this system. It should be noted that, this decision was made for a number of reasons, most notably, the fact that there are many local languages in these countries; many of which are still to have a writing systems i.e. they mostly are spoken languages. Considering the fact that these countries are multi-ethnic by essence, with different religious, cultural and linguistic traditions, the occurrence of contradictions and conflicts is relatively high. Taking a foreign language as the official language was therefore also a way to objectively avoid contradictions and conflicts between ethnic groups, since choosing the language of one ethnic group could have cause the dissatisfaction 
of another ethnic group.

70 years of French colonial history has affected the social structure of these countries to a point where only those who learn French can be actual members of the society. Because the language (or the main language) used by the most important institutions of this society such as public service, education, media, etc., is French. Menessy Gabriel (1994), discussing the language policies of French-speaking African countries, pointed out that the maintenance and continuation of French in these countries was due to the failure of national language planning. These countries not only failed to ensure the status of local language in language policy and planning, but also maintained the high status of French language from the colonial period. The sad reality then was that, citizens could "improve or upgrade" their standard of living through French education, whereas one could not enjoy the basic public services provided by the state without going through the French education system. Hence the assertion that: L 'Organisation sociale est telle d 'autre part que, La maitrise du Français est,dans Les faits la Première condition d 'accès à cette civilisation et ulterieurement gage de réussite dans un univers occidentalisé.) "In these 'westernized' societies, the social system itself makes the mastery of French language one of the necessary, even the most important, factor for participation in social life." In short, although choosing French as the official language at that time helped to solve the threat of conflicts between ethnic groups, and contributed to the political and economic development, and guaranteed unity in the daily life of the nation after independence, it is also the fundamental reason why these countries now face the threat of disappearance of their national languages. Simply put, sub-Saharan Africa is the region in the world where French is flourishing and where local languages are the least developed.

Again, speaking of native languages, it should be pointed out that this region is one of the most linguistically diverse in the world. Therefore, these French-speaking countries are in fact multilingual societies; some of them have as much as 200 local languages. For example, 200 languages are spoken in the Democratic Republic of Congo and 270 in Cameroon. Language planning in such a context becomes a real challenge for officials. Yet, using a foreign language as an official language is not only a form of discrimination against native languages but also a threat to them. As a result, languages in some of these countries are threatened with extinction or even have already begun to extinct. Some of these countries have taken positive steps to address this situation by upgrading the most important (in terms of influence, history, and number of speakers) of their native languages to Official or National languages. Congo, for example, has upgraded Lingala and Kituba to national language status. This kind of micro language planning might seem like only a small step forward, but it is an important step in the language planning of these countries. Today, several sub-Saharan African countries have upgraded some indigenous languages to official status along with foreign ones, giving both languages the same status under national law. Although, in practice, this decision has not yet produced a significant positive effect, and may not be immediately effective, it can at least prevent the extinction of languages, especially the major languages. The idea of major languages here come from the fact that, in some cases, a national language is spoken by a large proportion of the population. There are some countries where the national language is even more spoken in daily life than the official language.

It can be seen that African countries on the whole have taken some conscious actions in developing national languages. Today there is the Académie Africaine des Langues Acalan, a continent-wide institute for the study and development of African languages, a project sponsored by the African Union. The Institute of African Languages is a scientific body which aims to enhance the research and development of African languages with a view of promoting their use and promoting socio-economic and cultural exchanges among African countries, thereby contributing to the development of African languages and realizing the dreams of 
the African Union. It was officially launched on 8 September 2001 and is headquartered in Bamako, the capital of Mali. Within the framework of this project, countries test different language policy and planning models at the national level according to their own linguistic characteristics. As far as francophone countries in sub-Saharan Africa are concerned, after exploring some of the characteristics of their language policies, they can be divided into the following three typical paradigms :(1) countries with a common language and declining use of French; (2) countries without a common language with a rapid growth of the use of French; (3) other countries with more complex language circumstances. Each paradigm has its own characteristics, difficulties and challenges to be solved in language policy and planning. Therefore, the next section analyses the challenges and prospects of language policies in these countries due to the existence of French through case studies.

\section{Typical case analysis}

\subsection{Countries with a common language and a declining use of French}

Although such countries face the same problems of multilingualism, they have the advantage of having at least one national language. This language is relatively prominent in a sense and has many features worthy of further analysis. Senegal, Mali and the Central African Republic can be named here as typical cases.

First, this common language is widely used and understood by more than $50 \%$ of the total population in their daily lives. In some countries, this figure even raises up to 95 percent. It is a national language for some, but a common language for others; Because this language is widely used in daily life in activities such as trade and important inter ethnic communication activities, people of other ethnic groups learn and use it in order for a better integration into the society. Bambara, for example, is a national language of Mali. It is spoken as a mother tongue by about $40 \%$ of the country's population and as a lingua franca by $80 \%$ of the country's population (Mbodj-Pouye et Van den Avenne 2007). It is also spoken in some neighbouring countries. Malian scholars have made many research on Bambara and even created a writing system for the language. As a result, Bambara is widely used for the Malian Adult Literacy Project, whose students have achieved remarkable results in daily reading and writing, and the language is also used alongside French in all aspects of the country's daily life (Dumestre 1998).

This common language has great social influence in social and ethnic communication. In some countries, it is one of the best languages to broadcast in the media or communicate with people in public services. Take Central African Republic as an example. In the national radio channel, more than $50 \%$ of the programs are broadcasted in the local language, Sango. In national public life, especially in government public service, such as the police, government institutions, and even the country's official news broadcasts, everything is bilingual in French and Sango. In addition, in the daily social life, if the mother tongue of a couple in a family is different, they will use Sango as the lingua franca in the family environment. Moreover, in settings such as the market or any other trading activities between different ethnic groups, the language of communication is also Sango (Gerbault 1987; 1990). Sango is therefore a common language spoken throughout the Central African Republic. It is derived from the combination of two languages; the first is the native language Ngbandi, which is the main component of the language's vocabulary, grammatical structure, etc. the other language, French, provides a large number of lexical sources to Sango. Sango became the national language at independence in 
1964 and was later upgraded to official status along with French in 1991. The current language policy in the Central African Republic promotes the development of Sango in all its aspects and the language has even entered the national education system.

Secondly, such a common language in these countries is usually source of national pride to the citizens of the country, because they can see their identity displayed in the use of this language. Therefore, when people from different ethnic groups learn this language, they do not worry about the disappearance of their own ethnic language, because they see it as one of their own languages and they feel proud of using it. It gives everybody a sense of belonging and unity. In Senegal, for example, 80 to 90 percent of the population speaks Wolof, while French is actually spoken by only a third of the population. Many Senegalese regard Wolof as their own language, and feel that wolof reflects their identity, rather than French. In terms of language policy, Wolof is the only de facto common language in the country, although wolof and five other languages have been designated as national languages by the government. Wolof is widely used in national life and has been one of the languages used in the national assembly since 2014. Wolof is far more widely used in the media than French. In the education system, especially in primary education, many primary school teachers use Wolof for basic education. This method is in line with what linguists have found which is that, encouraging the use of a child's mother tongue in primary education produces better learning results on the part of the learner. The Senegalese government, on the other hand, became worried about this phenomenon. The Ministry of Education is even worried that the French language will eventually extinct in Senegal, so it has launched a number of programs to train primary school teachers and improve the quality of French teaching. In addition, the linguistic situation in Senegal has been noted in many reports of La Francophonie (OIF), noting the increasing dominance of Wolof in Senegal. Given that this is an organization whose aim is to promote The French language around the world, the use of French language is under threat at some point, and their interest is in reviving the French language in the country, not the education the children receive, let alone the quality of the education system.

The peculiarity of these countries therefore is that, they all have a powerful, socially influential language that has been spoken and accepted by all. This can serve as a force to further develop the language and eventually make it the official language of the country. So, these countries have been able to elevate the language to the status of the official national language and make it used in all areas of the country. In the area of language policy and planning in sub-Saharan Africa, these countries, with or without conscious effort of their own, are in a better position or let's say are doing way better than others.

\subsection{Countries without a common language with a rapid growth of the use of French}

In this category, countries like Gabon, Benin can be used as examples. What makes these countries special is that, first of all, they don't have a prominent indigenous language, and French is developing very fast in the society. Here, French is popular and rather welcomed among the people. In addition, the development of local languages is not only limited, and has not yet entered the country's language policy, but also is in a relatively neglected state. As a result of this phenomenon, the use of French is increasing and it is widely used in many important areas of society. In fact, some of these countries have not taken any measures to protect and promote the development of their local languages, but rather, are working hard to introduce even more foreign languages into their national education systems and their own language policies. Gabon, 
for example, is a country with a small population in central Africa where French is the only official language and there is no mainstream local language. Fang, the most influential local language, is spoken by only $32 \%$ of the country. According to La Francophonie (OIF), 80\% of Gabonese speak French, and even more; $99 \%$ of citizens living in Libreville, the capital, can read and communicate in French (Ndinga 2005, Italia 2015). These statistics speak volumes about the situation of the French language in Gabon, knowing that the capital alone is home to half of the total population of the country. At present, many of the younger generation of children are use to speaking French both at home and in school, and they do not have any native languages other than French. The proportion of these so-called native French speakers has reached $30 \%$ (this is a phenomenon that many African countries face today because of the rising literacy rates). Due to the widespread use and flourishing of French, the development of local languages has received little attention. In addition, due to the "English fever" brought by the era of globalization, the Gabonese government decided to set English as one of the country's official language in 2012, and then introduced English into the education system. Whereas, the development of local languages has never been a concerned for the government; it can only rely on the efforts of linguists and researchers to develop. This is confusing, because it is possible to introduce new languages into a society through education. Language policies such as the Gabonese government's, in which education plays an important role in language use and development, are detrimental to indigenous languages. In addition, such language policies that only focus on foreign languages and ignore local ones, actually promote the increasing disappearance of these local languages. Unfortunately, most French speaking countries in sub-Saharan Africa fall into this category, and this phenomenon gives no hope as for the future of their local languages.

\subsection{Other countries with more complex language circumstances}

The third category is the most complex, although to some extend it reflects the overall situation of language problems in African countries. Cameroon and Rwanda can be used as example.

Cameroon is a typical multilingual country, with some 270 indigenous languages and two official languages, English and French. According to statistics, 22 percent of Cameroonians are English speakers and about 48 percent are French speakers. This relatively complex language situation has brought a lot of inconvenience to the government. Although some efforts have been made in the development of indigenous languages, and many of them have been able to develop, the choice of one of them as one of the country's official languages remains an unsolved problem. At present, Cameroon's national languages are still at the research and experimental stage and have not yet been introduced into important aspects of the country's life such as the public service. In Cameroon, for example, the government decided during the pilot phase of its indigenous language development program to divide the country into different linguistic zones and have schools in each region teach the region's most prominent language. As a result, secondary education learners in Cameroon today have the opportunity to attend national language classes and participate in related activities.

Another complex case is that of Rwanda. Rwanda is a rare case of Unilingualism, which is rare among African countries. Indeed, about $91 \%$ of the population can speak Kinyarwanda, the country's main indigenous language. Rwanda has always had Kinyarwanda and French as the official languages of the country, and in 2003 decided to introduce English into the national language policy and make English one of the official languages. In 2008, Rwanda even switched its education system entirely from French to English, 
and various government services moved from French to English over time as well. Regarding this reform, the President Paul Kagame pointed out that "We give priority to the use of English because it helps us to empower our children and further strengthen our vision of development." Thus, Kinyarwanda is currently a language of instruction in primary education in Rwanda, but English is the language of instruction from grade 5 onwards. French is taught henceforth simply as a foreign language in a few classes a week in primary and secondary education.

From these two cases, it is clear that, French influences the language policies of various countries to some extent. In Rwanda, where the government hopes to weaken the use of French, the trend is towards English. Although Cameroon has developed several indigenous languages, the official status of English and French remains unshakable, and the language debate has focused more on the status of English and French than on indigenous languages, which is a huge disadvantage to the eventual goal of establishing a national language as the official language of the country. In fact, these countries' complex linguistic environment and the huge influence of French on them are only a microcosm of Africa.

\section{Conclusion and suggestions}

French undeniably has a huge influence on language policy in sub-Saharan Africa. Although it is now an official language in many of these countries, not all of their citizens are proficient in the language due to deficiencies in their education systems and infrastructure. So even though French is widely spoken in the public sphere, there are still too many people who have not received formal French education to meet the country's so-called language policy goals. In the language policy of these countries, the development of indigenous languages is hindered by the elevation of French to the status of the official language. Local governments and citizens themselves do not see the value of local languages, which are therefore not seen as a resource that can be used to build national identity, integrate and strengthen their economies. In addition, education, mainly in French, is seen as the only way into the modern world, leaving even fewer opportunities for the development of indigenous languages in such context. African countries as a whole have a wrong way of thinking about their own languages. local languages are more than important because they are the core of people's culture and identity. Therefore, many researchers believe that the African continent as a whole can take advantage of its multilingual context to promote the development of the continent. Even, many contemporary scholars assert that the development of Africa is actually inseparable from African languages, and African countries need to formulate and implement some corresponding language policies, so that they can introduce local languages into the education system, public services, foreign relations and media, in a bid to attach an economic value to African languages. In this way, African languages will contribute to the development of African countries. In his book Language Policy and Economics: The Language Question in Africa, Nkonko Kamwangamalu in (Benson 2018), also proposed this idea of developing African indigenous languages from an economic perspective. He believes that, only by adding value to African languages economically and making African languages generate concrete economic returns in real life can African policy makers change the existing language policies and help African languages develop sustainably. He further pointed out that, this wish could be achieved through prestige planning for African languages which will promote their dissemination and practical use.

On the other hand, the French language is not useless or only harmful to these countries. In fact, French is a resource that can be used to further improve the education systems of these countries, as well as to 
develop and promote indigenous languages.

To sum up, the French language, like other colonial heritages, should be seen as a resource, an advantage that can help African countries meet the challenges of globalization while preserving their identity. Hopefully, in the future, the African Union through its Academy of Languages and with the help of African countries, particularly sub-saharan African countries, will be able to develop their own language. Only then, will the use of French alongside national languages promote an African society ready to face the challenges of globalization and remain rooted in its own culture.

\section{Acknowledgements}

\section{References}

ACALAN. (2010). Rapport d'activités de l'Académie africaine des langues depuis son installation le 08 septembre 2008 . ACALAN Rapport d'activités, Bamako.

Mbodj-Pouye, A., Van den Avenne, C. (2007). « C'est bambara et français mélangés » Analyser des écrits plurilingues à partir du cas des cahiers villageois recueillis au Mali. Éditions de la Maison des sciences de l’homme 120, p. 99-127.

Benson, C. (2018) Language policy and economics. The language question in Africa Book review. Current Issues in Language Planning (19)2, p. 226-230.

Dumestre, G. (1998). Le bambara véhiculaire du Mali. In "Les langues d'Afrique subsaharienne” Suzy Platiel \& Raphaël Kabore, Editors. Faits de langues, Paris, p. 121-127.

Gerbault, J. (1987). Utilisation des langues et attitudes : la montée du Sango. Bulletin de l'observatoire contemporain du français en Afrique noire, p.8.

Gerbault J. (1990). Modes d'appropriation langagière en République Centrafricaine. Bulletin du Centre d'étude des plurilinguismes 11, PP. $35-70$.

Gadet, F. (2011). Compte rendu « Calvet, Louis-Jean. -Histoire du Français en Afrique. Une langue en copropriété ?. Organisation Internationale de la Francophonie, Éditions Écritures, p. 220.

Italia, M. (2015). La variation du français parlé au Gabon. Voix plurielles, (12)1.

Manessy, G. (1994). Pratique du français en Afrique noire francophone. In Le français en Afrique noire, fait d'appropriation Carole de Féral \& Francis-Marie Gandon, Editors. Langue française,104, p. 11-19.

Ndinga, S. (2005). Politique linguistique et éducation au Gabon : état des lieux. Journal of Education, (4)1, p. 65-78.

Nojea, T. (2017). Le français et l'Afrique subsaharienne. Deuxième partie : L'usage du français en Afrique Noire. ANADISS, (1) 23, p.145-152.

Pasch, H. Le Sango, langue officielle de la république centrafricaine. In "Les langues d'Afrique subsaharienne" Suzy Platiel \& Raphaël Kabore, Editors. Faits de langues, Paris, p.111-120.

Webb, V. (2004). African languages as media of instruction : Stating the case. Language Problems and Language Planning, 28(2), p. $147-173$. 